\title{
偏心接合した平行弦卜ラス平板の力学性状に関する研究 A STUDY ON STRUCTURAL PROPERTIES OF DOUBLE-LAYER GRIDS WITH ECCENTRIC JOINTS
}

\author{
鈴木敏 郎*, 小河利 行**, 木村祥 裕***, 今井一郎**** \\ Toshiro SUZUKI, Toshiyuki OGAWA, Yoshihiro KIMURA \\ and Ichiro IMAI
}

\begin{abstract}
The ultimate strength of double-layer grids is determined by the member buckling and yielding. After buckling, the grids lose most of their strength. In this paper, we investigate the structural properties of double-layer grids with eccentric joints to improve deformation capacity. These grids consist of units of truss connected together by eccentric joint members. The loading tests and numerical analysis are carried out to investigate the influence of the rigidity of eccentric joint members and the difference of the progressive collapse mechanisms. As the result, these grids show stable behavior compared with that of the conventional grids.
\end{abstract}

Keywords : eccentric joint, unitization of truss, structural properties, double-layer grid, elasto-plastic analysis, loading test

偏心接合，ユニット化，力学特性，トラス平板，弾塑性解析，载荷実験

\section{1. 序}

屋根構造等の大空間構造に用いられる平行弦立体トラス平板（以 下，トラス平板）では設計上，雪荷重や風荷重等の鉛直荷重が支配 的となることから，通常強度設計による検討がなされる。トラス平 板において部材が圧縮力を受け，いったん座屈すると，保持できな くなった軸力が隣接部材に再配分され，次々と座屈を引き起こし， トラス平板全体の耐力は低下する。トラス平板の強度性状, 座屈後 挙動を取り扱った研究は数多く見受けられ，その力学挙動は総括的 に把握されている5)。

また，トラス平板は人工地盤のような長期に極めて大きな鉛直荷 重を支持する構造物にも用いられる。屋根構造の場合とは異なり， 地震を考慮して，鉛直荷重および水平荷重に対する検討が必要とさ

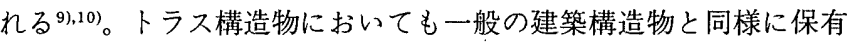
耐力, 塑性変形性能を考える必要がある。

著者らはトラス構造物の塑性変形性能に関して研究を行い，その 中でトラス構造物がある程度の変形性能を確保するためには個材の 細長比を小さくしなければならないという知見を得ている33),4。の 場合，トラス構造物の崩壊形式は一部の圧縮弦材の座屈によるもの であり，他の多くの部材は健全なままである。

トラス構造物の崩壊形式を変化させて, 変形性能を確保する手法 として，個材座屈を生じる可能性のある圧縮弦材に対して補強す
$ろ^{2)}$, 圧縮弦材の断面性能を大きくする 圧縮弦材の座屈後，耐力低下を抑制する方法として，著者らはトラ 又梁の中立軸近傍に新たに中間材を配した梁を提案し，そのような 梁の塑性変形性能について把握している13)。これらは比較的構成部 材が少ない平面トラス梁等の場合には有効な方法であるが，トラス 平板の場合には対象となる部材の配置や，トラスの構成そのものが 複雑となってしまう。そこで著者らはトラス平板の構成をあまり変 えることなく，靶性を改善するために圧縮弦材の節点で偏心接合し たトラス平板を提示し，その力学挙動について検討している ${ }^{14)}$ 。トラ ス部材の節点で偏心接合した場合, 軸力に加えて二次的な曲げモ一 メントが作用するために，圧縮弦材の座屈による急激な耐力低下を 抑えることができる。

本研究で提案するトラス平板の特徵は, あらかじめユニットトラ スを作成し，順次連結することで構築作業を簡略化している点であ る。ユニットトラス同士を接合材で連結することで，節点に集まる 部材数を低減し，高い精度を維持できる。

このトラス平板は各接合材により偏心接合されていることから, 圧縮弦材の座屈後の急激な耐力低下を緩和できる。偏心接合材の断 面性能を適切に調節することでトラス構造物全体の変形能力は大幅 に向上し，耐震性に優れたトラス平板となりうる。そこで円形中奏 棒によるトラス平板を対象として，偏心接合したトラス平板につい

\footnotetext{
注）本論支の一部は参考文献11，12）において発来している。

* 東京工業大学名誉教授・正博

** 東京工業大学工学部建築学科 教授・工博

*** 東京工業大学工学部建築学科 助手 ·博士 (工学)

**** (侏梓設計代表取締役尃務
}

Prof., Emeritus, Tokyo Institute of Technology, Dr. Eng.

Prof., Dept. of Architecture, Faculty of Engineering, Tokyo Institute of Technology, Dr. Eng.

Research Assoc., Dept. of Architecture, Faculty of Engineering, Tokyo Institute of Technology, Dr. Eng.

Azusa sekkei Co., Ltd., Representive Managing Director 
て単調載荷実験を行い，基本的な力学性状を明らかにする。そして 数值解析により，このようなトラス平板と偏心のないトラス平板の 崩壊機構を比較し，偏心接合の影響を把握する。

\section{2. 偏心接合した平行弦トラス平衵の力学特性}

\section{1 試験体}

試験体はFig. 1に示すような偏心接合した平行弦卜ラス平板で あり，Fig. 2 に示す単位ユニットトラスを 9 つ用いて構成されてい る。試験体はまず，単位ユニットトラスを作成し，それを偏心接合 材で連結して組み上げている。試験体はプラット型の平面卜ラス梁 で構成される直交交差型のトラス平板で水平方向の剛性が低いこと から, Fig. 2 における点線で示す位置に水平補剛材を用いている。試 験体は全部で 2 体で，偏心接合材の剛性をパラメータとしており， 偏心接合材のせん断変形が先行するタイプと弦材の個材座屈が先行

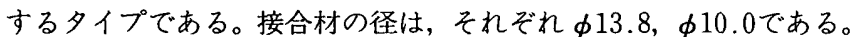

Table 1 に部材特性を示す。弦材，斜材および束材に $\phi 16$, 水平補
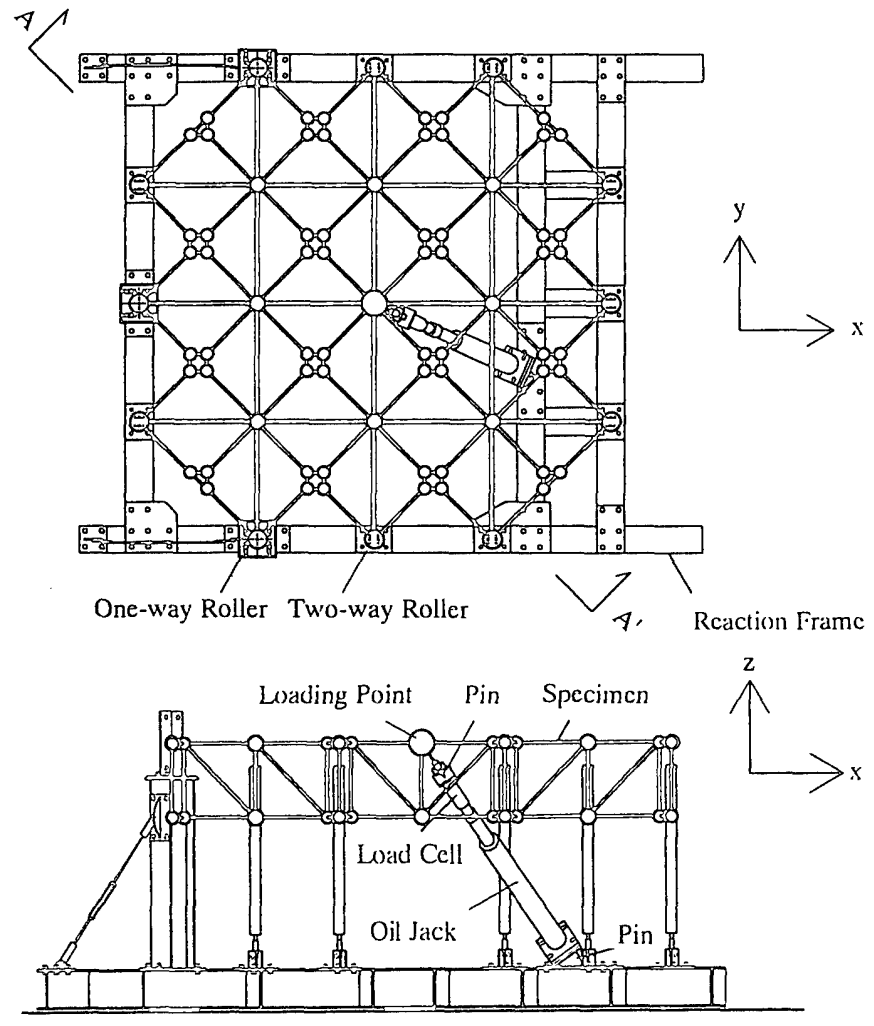

Fig. 1 Specimen and test set up

Table 1 List of members

\begin{tabular}{|lll||r|}
\hline Length of chord member & $(\phi 16)$ & $\mathrm{Lf}(\mathrm{cm})$ & 45.5 \\
Length of level stiffness member & $(\phi 22)$ & $\mathrm{Ls}(\mathrm{cm})$ & 75.0 \\
Length of web member & $(\phi 16)$ & $\mathrm{Lw}(\mathrm{cm})$ & 58.0 \\
Moment of inertia & $(\phi 16)$ & $\mathrm{I}\left(\mathrm{cm}^{4}\right)$ & 0.32 \\
Moment of inertia & $(\phi 22)$ & $\mathrm{I}\left(\mathrm{cm}^{4}\right)$ & 1.15 \\
Slenderness ratio of chord member & $\lambda f$ & 113.6 \\
Slenderness ratio of level stiffness member & $\lambda \mathrm{s}$ & 136.4 \\
Slenderness ratio of web member & $\lambda \mathrm{w}$ & 144.9 \\
\hline
\end{tabular}

剛材に $\phi 220$ 中奏棒をそれぞれ用いている。ただし，ユニットトラ ス中央の束材は $\phi 22$ を用い，加力点につながる束材は加力治具とな るように $\phi 30$ としている。トラス平板は $3,000 \mathrm{~mm} \times 3,000 \mathrm{~mm}$ で, 高 さは $360 \mathrm{~mm}$ である。細長比入は節点間距離を座屈長さとした場合， 弦材で113.6, 斜材で136.4, 水平補剛材で144.9である。Table 2 に 鋼材の機械的性質を示す。試験体に使用した各部材の材質は SS400 で，偏心接合材のみ SCM440である。引張試験は各径の中実棒につ いて JIS 規格 2 昂試験片を用いて行った。なお, 降伏応力度の算定は $0.2 \%$ $\%$ セッ法によっている。接合部は中空ボールジョイントを 使用したねじ込み接合としている。ボ一ルの大きさは，支持部で外 径 $120 \mathrm{~mm}$, 加力部で $160 \mathrm{~mm}$ ，ユニットトラスの中央は $100 \mathrm{~mm}$, 端部 は80mmである。Fig. 3 にユニット接合部の詳細を, Table 3 に偏心 接合材の部材特性を示す。偏心量 $\left(l^{\prime}\right)$ は $107.1 \mathrm{~mm}$ であり，これは 図中ユニット中央ボールから端部ボールまでの長さ $\left(L_{f}+l\right)$ の1/7

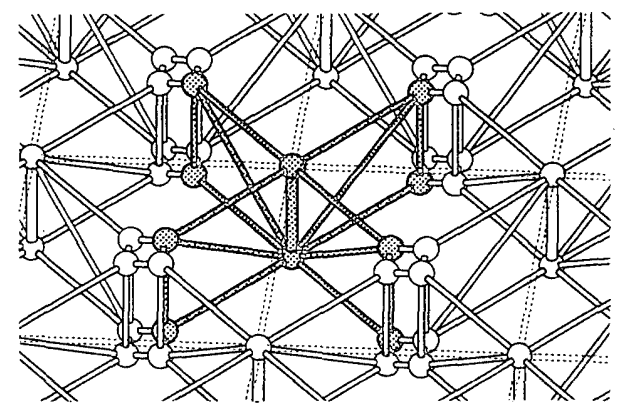

Fig. 2 Unit of truss

Table 2 Material properties

\begin{tabular}{|c|cccccc|}
\hline TEST-PIECE & $\begin{array}{c}\text { E } \\
\left(\mathrm{t} / \mathrm{cm}^{2}\right)\end{array}$ & $\begin{array}{c}\text { Est } \\
\left(\mathrm{t} / \mathrm{cm}^{2}\right)\end{array}$ & $\begin{array}{c}\text { Oy } \\
\left(\mathrm{t} / \mathrm{cm}^{2}\right)\end{array}$ & $\begin{array}{c}\text { Ol } \\
\left(\mathrm{t} / \mathrm{cm}^{2}\right)\end{array}$ & Y.R & $\begin{array}{c}\text { Elong. } \\
(\%)\end{array}$ \\
\hline SS400 & 2143 & 35.6 & 3.25 & 4.66 & 0.70 & 33.1 \\
SCM440 & 2159 & 24.6 & 9.63 & 10.40 & 0.93 & 13.4 \\
\hline
\end{tabular}
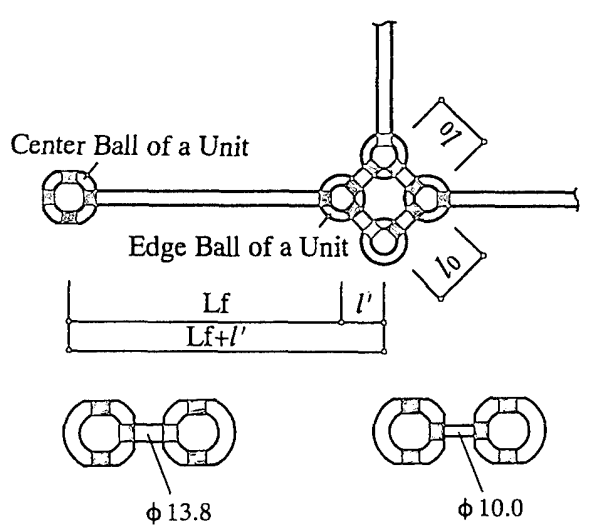

Fig. 3 Eccentric joint

Table 3 List of eccentric joint

\begin{tabular}{|c|c|c|c|c|}
\hline TYPE & $\begin{array}{c}\text { I } \\
\left(\mathrm{cm}^{4}\right)\end{array}$ & $\begin{array}{c}\text { lo } \\
(\mathrm{cm})\end{array}$ & $\begin{array}{c}l^{\prime} \\
(\mathrm{cm})\end{array}$ & $\begin{array}{c}l^{\prime} /\left(\mathrm{Lf}+l^{\prime}\right) \\
(\mathrm{cm})\end{array}$ \\
\hline \hline E-13.8 & 0.180 & 15.15 & 10.71 & $1 / 7$ \\
$\mathrm{E}-10.0$ & 0.049 & 15.15 & 10.71 & $1 / 7$ \\
\hline
\end{tabular}




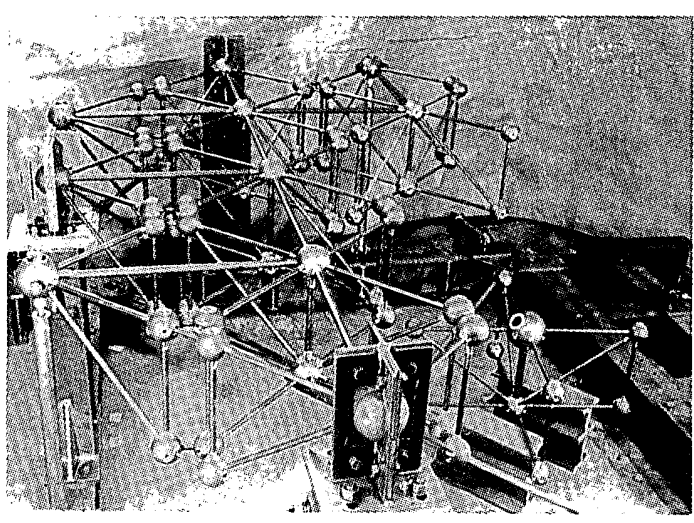

Photo. 1 Specimen

に相当する。

Photo. 1 に試験体の作成過程を示す。試験体はまず単位ユニット トラスを組み立て，それを偏心接合材によって連結している。ここ で上弦材の初期不整量は上弦材長さ $454 \mathrm{~mm} の 1 \%$ 程度, $5 \mathrm{~mm}$ 以内 に収まっており，施工精度の高いトラス構造になっている。

\section{2 載荷装置及び実験方法}

実験装置をFig. 1 に示す。本実験では地震時の水平外乱を想定 し，鉛直荷重と水平荷重を同時に受けるトラス平板の力学性状を検 討する。そこで図中, 上弦材の中央節点から $(X, Y, Z)=(7,-3,-$ 7）となるよjに荷重方向を設定している。ただし，ジャッキ端部を ピン支持しているため, 加力点ボールの変位べクトル方向は任意で あり, 荷重ベクトル方向は常に加力ボールとジャッキ支持端とを結 ぶ線上にある。載荷は油圧式ジャッキにより集中荷重を加えており, 荷重の検出には載荷節点とオイルジャッキの間にセットしたロード セルにより行っている。また, 試験体外周支持端部の境界条件は鉛 直変位を拘束し，うち 3 節点を一方向ローラ一支持，その他の 9 節 点を二方向ローラー支持としている。

\section{3 接合部曲げ試験}

平行弦卜ラス平板の載荷実験に伴い, 接合部の回転バネ岡性を調 べる目的で，ボールジョイント接合部を中央に含む部材の繰返し曲 げ実験を行っている。ここではユニット材と偏心接合材の回転バネ 岡性を比較するために $\phi 16$ の中実棒について行っており，鋼種は SS400，SCM440である。Fig. 4 に載荷方法の概略を示す。試験体は 偏心接合されているために各部材には軸力だけでなく，曲げとせん

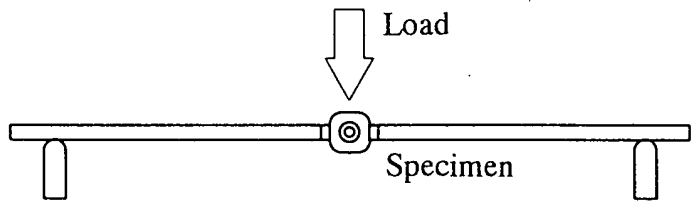

Fig. 4 Loading system for bending tests

Table 4 Elastic rotational spring rigidity

\begin{tabular}{|c|c|c|}
\hline & SS400 & SCM440 \\
\hline \hline $\mathrm{k} \theta(\mathrm{ton} \cdot \mathrm{cm} / \mathrm{rad})$ & 397.5 & 742.5 \\
\hline
\end{tabular}

断力が同時に作用することになる。載荷形式は両端単純支持で中央 集中荷重としている。実験結果から得られた接合部回転バネ剛性を Table 4 に示す。部材の鋼種の違いによって接合部の回転バネ剛性 が変化しており，SS400に比べて SCM440の部材のバネ剛性は約 2 倍程度となっている。

\section{4 偏心接合材の曲げ剛性の異なるトラス平板の力学性状}

Fig. 5 に両試験体の加力点における荷重変形関係を示す。縦軸は 荷重べクトルの大きさを，横軸は載荷点での変位べクトルの大きさ を示している。また, Table 5 にそれに对応する諸データを示してい る。両試験体ともに接合部の偏心量は等しいが，偏心接合材の曲げ 剛性は E-10.0に比べて E-13.8は約 4 倍であり，E-13.8の初期剛性 は E-10.0の1.5倍, 初期座屈耐力は 1.3 倍程度となっている。偏心接 合材の曲げ剛性を適切に選択することで，初期剛性，座屈耐力を調 節することができる。また，初期座屈耐力に対する最大耐力の上昇 率は E-10.0の方が高くなっている。偏心のないトラス平板では地震 等の外力を受け，座屈を生じると軸力を保持できなくなった部材の 応力が隣接部材に再配分され, 次々と座屈を引き起こす。そのため, 初期座屈によって最大耐力がほぼ決定され，急激に耐力劣化してし まう。しかし，本論文で提案している偏心接合したトラス平板は初 期座屈後も耐力は上昇しており，E-10.0で最大耐力は初期座屈耐力

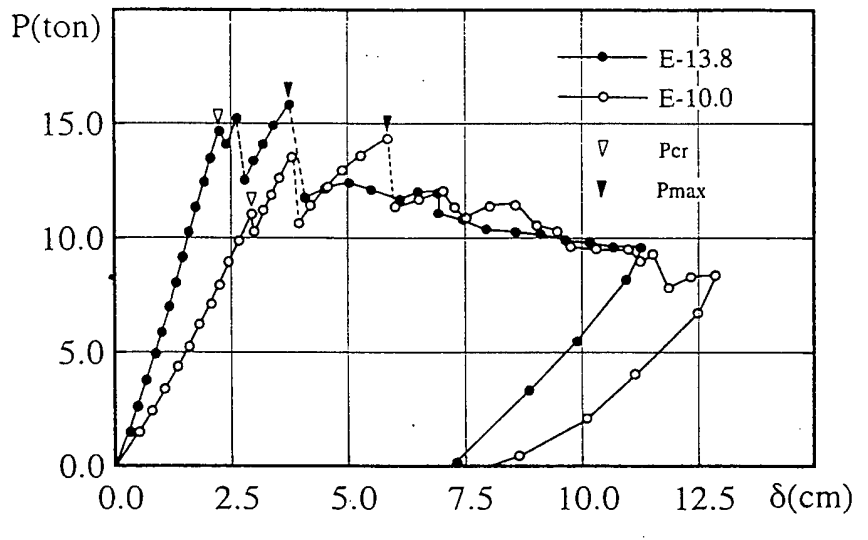

Fig. 5 Load displacement curve

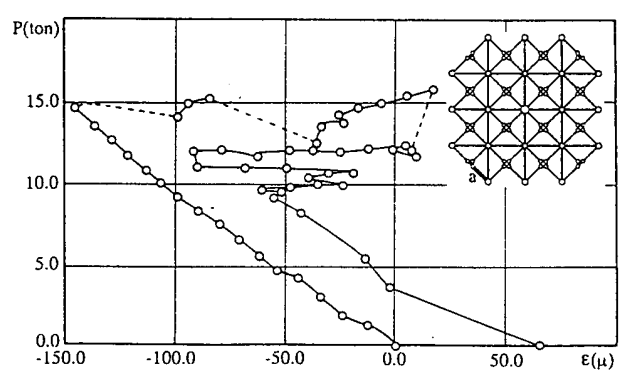

Fig. 6 Load axial strain curve

Table 5 Results of experiment

\begin{tabular}{|c|c|c|c|c|c|c|c|}
\hline Specimen & $\begin{array}{c}\text { Initial Stiffness } \\
\left(\mathrm{V} / \mathrm{cm}^{2}\right)\end{array}$ & $\begin{array}{c}\text { Initial Buckling } \\
\text { Strength } \\
\text { Pcr(ton) }\end{array}$ & $\begin{array}{c}\text { Deformation } \\
\text { at Pcr } \\
\delta c r(\mathrm{~cm})\end{array}$ & $\begin{array}{c}\text { Maximum } \\
\text { Strength } \\
\text { Pmax(ton) }\end{array}$ & Pmax/Pcr & $\begin{array}{c}\text { Deformation } \\
\text { at Pmax } \\
\delta \max (\mathrm{cm})\end{array}$ & $\delta \mathrm{cc} / \delta \max$ \\
\hline \hline E-13.8 & 6.41 & 14.77 & 2.30 & 15.79 & 1.07 & 3.77 & 1.63 \\
E-10.0 & 4.05 & 11.10 & 2.94 & 14.29 & 1.28 & 5.88 & 2.00 \\
\hline
\end{tabular}




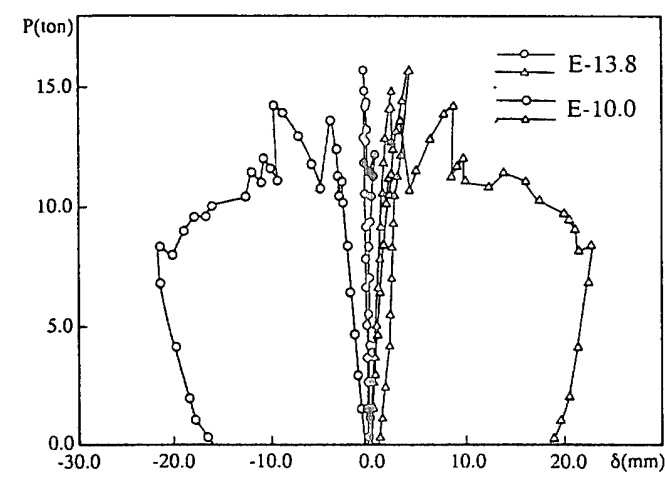

Fig. 7 Distance of eccentric joints
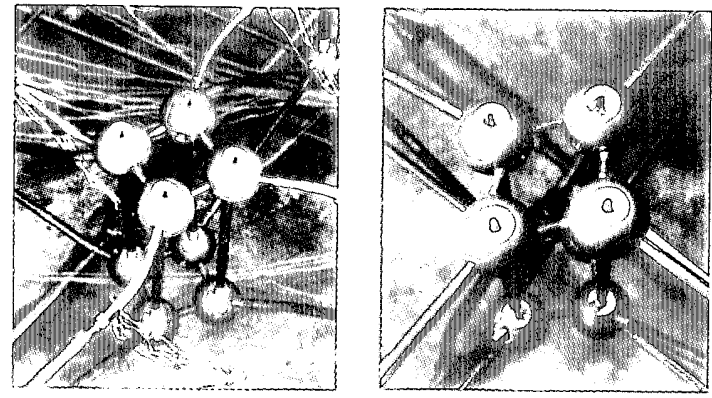

Photo. 2 Deformation of eccentric joints

の1.3倍，E-13.8では1.1倍になっている。そして個材座羞を引き起 こしながら，変形量を増大させ，最大耐力を迎えている。このとき 両試験体の最大耐力は $10 \%$ 程度しか差がなく，偏心接合材の剛性が 最大耐力に及ぼす影響は小さい。また，両試験体ともに最大耐力後 の劣化は䌅やかで，最大耐力の約 $80 \%$ である $12.0 \mathrm{t}$ 程度で停留して おり，安定した力学挙動を示していることが分かる。

Fig. 6 に試験体 E-13.8における荷重と上弦材（図中a）の軸Uず みとの関係を示す。載荷当初，この部材は線形性を保ちながら，圧 縮力を負担しているが, 初期座屈が生じると応力状態が一変し，引 張力を負担するようになる。その後，斜材の座屈が発生しているが， 急激な耐力低下はない。座屈の発生に伴い，圧縮力，引張力を受け 持ちながら応力状態がその都度変化しているのが分かる。

Fig. 7 に荷重と加力点付近の偏心接合部における節点間距離との 関係を示す。E-13.8では最終変形に至るまで偏心接合部では変形が ほとんどなく，水平方向に節点のずれは生じていない。それに対し て E-10.0では初期座屈後徐々に変形が増加し, 最終的に偏心接合材 で破断が生じている。しかし，破断による全体挙動への影響はほと んど見られず，緩やかに耐力が低下している。

Photo. 2 に偏心部の変形状態を示す。E-13.8では偏心接合部が剛 体回転し，これに連結している弦材で曲げ変形を生じている。 $\mathrm{E}$ $-10.0 て ゙ も$ 偏心接合部の㴊体変形は見られたが, 特に加力点付近の偏 心接合部では写真のように節点が相対的に移動してひし形に変形し ている。これは偏心接合部で水平方向ならびに鉛直方向へのせん断 変形が生じていることを示している。偏心接合材の剛性を変化させ ることで，トラス全体の崩壊形式は異なるが，弦材座屈が先行する $\mathrm{E}-13.8$, 偏心接合部のせん断変形が先行する E-10.0のどちらも安 定した力学挙動を示している。
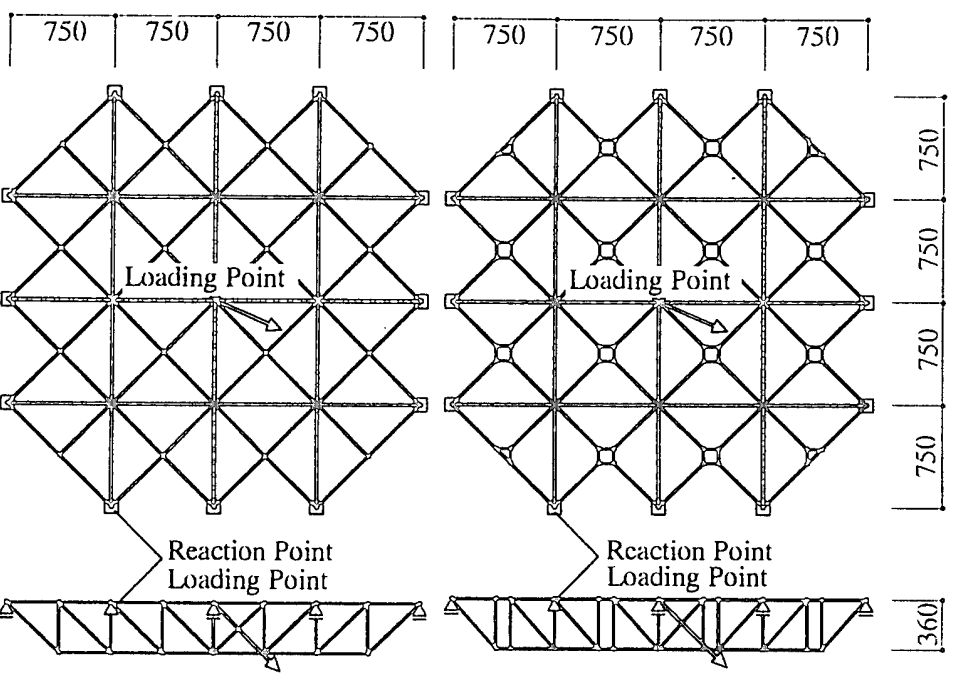

Fig. 8 Analysis models

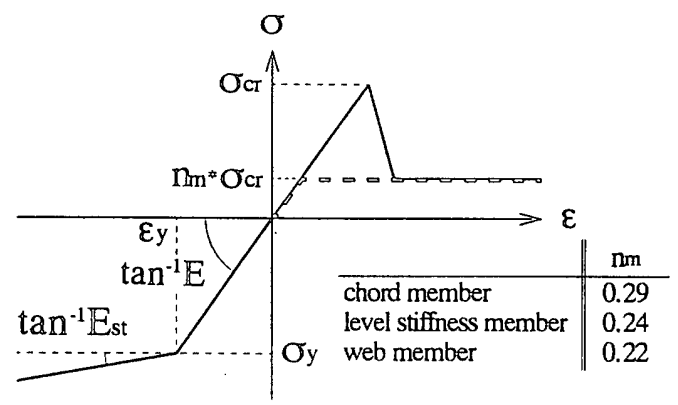

Fig. 9 Stress strain models

\section{3. 平行弦トラス平视のカ学性状に対する偏心接合の勃果}

偏心接合した平行弦卜ラス平板の崩塤機構を把握するために数值 解析を行う。特に偏心接合したトラス平板と偏心のないトラス平板 の崩壊機構の違いを検証する。

\section{1 数值解析概要}

Fig. 8 に解析モデルを示す。解析対象は図に示すように接合部に 偏心のないトラス平板及び偏心接合したトラス平板である。支持条 件及び荷重条件は実験と同じである。また，接合部の曲げ試験より 得られた接合部の回転バネ剛性が岡接合に近いことから, 数值解析 では概略的に剛接合としている。解析法は幾何学的及び材料非線形 を考慮した有限要素法による弾塑性大変形解析》である。応力ひず み関係は Table 2 の引張試験結果を参考にして bi-linear 型にモデ ル化しており，トラス部材は実験と同様，円形断面の中実棒である。 また, ここで数值解析を行うにあたって, 文献 6)を参考にして以下 の仮定を行う。

1) 引張部材の応力Uずみ関係は bi-linear 型とし, 降伏後も一定の 耐力を維持できる。

2) 圧縮部材が座屈耐力（許容耐力）を上回り，座屈したと判定さ れた場合，部材の耐力は座屈耐力に応じて低減する。その際，座 屈部材に Fig. 9 に点線で示す新たな応力ひずみ関係を与之，初期 の形状から再度解析し直す。圧縮座屈した部材の耐力を材料的に 取り扱うことで, 部材の座屈後挙動を簡略的に評価している。前 


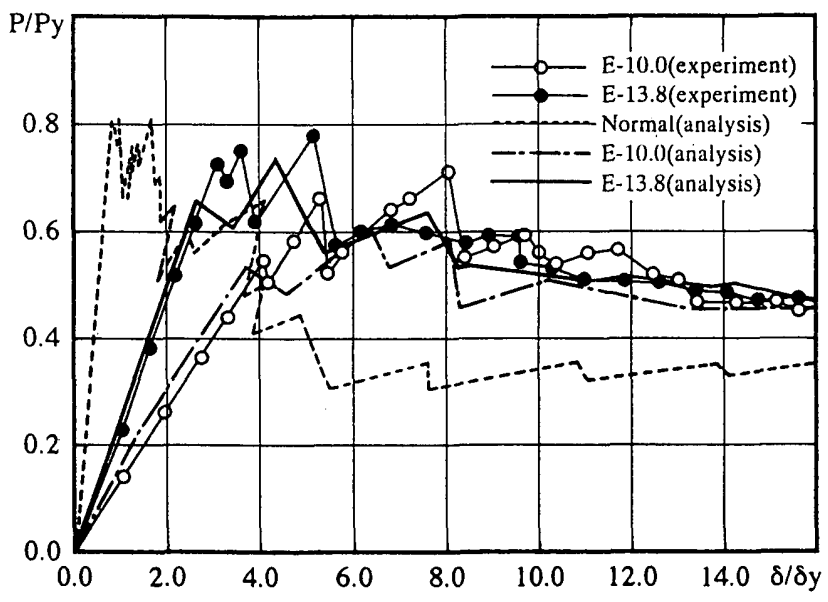

Fig. 10 Load displacement curve

の計算で追跡した変形以降を順次包絡することで, 架構の挙動を 近似的に把握している。圧縮部材の座屈応力度 $\sigma_{c r}$ は(1)式による ものとする。(1)式に示される $\lambda_{e}$ は材料特性を考慮した各部材の有 効細長比であり，ここでは各節点を剛接合としていることから座 屈長さは節点間距離の 0.5 倍とする。また, 圧縮部材の座屈後の耐 力停留值は Paris の解)を用いて, $e_{0}=5.0$ として座屈応力度 $\sigma_{c r}$ に対する耐力停留値の比 $n_{m}$ を(2)式のように定めている。

$$
\begin{array}{ll}
\sigma_{c r}=\left\{1-0.4\left(\frac{\lambda_{e}}{\Lambda}\right)^{2}\right\} \sigma_{y} & \left(\lambda_{e} \leq \Lambda\right) \\
\sigma_{c r}=\left(\frac{\pi}{\lambda_{e}}\right)^{2} \sigma_{y} & \left(\lambda_{e} \geq \Lambda\right) \\
\frac{1}{n_{m}^{2}}=\cos ^{2}\left(\frac{\pi n_{m}}{2}\right) \frac{e_{0}}{2} \lambda_{e}^{2} & \\
\text { ここで, } \lambda_{e}=\sqrt{\varepsilon_{y}} \lambda, \Lambda=\sqrt{\frac{\pi^{2}}{0.6}} \text { である。 }
\end{array}
$$

3 ）偏心接合したトラス平板では載荷当初から軸力のみならず, 曲 げモーメントの影響も大きいことから，圧縮部材の許容耐力は前 項で規定された座屈耐力もしくは部材が圧縮曲げにより降伏した ときの耐力のいずれか小さいほうの值とする。

Fig. 9 中の表に弦材, 斜材, 水平補岡材の座屈耐力に対する耐力停 留值の比 $n_{m}$ を示している。 $n_{m}$ は材料特性が同じ場合, 部材の細長 比のみに支配される。本論文で使用した部材の細長比では $0.2 \sim 0.3$ 程度となっている。

これらの仮定によって数值解析を行い,トラス平板の力学性状に 偏心接合が及ぼす影響を検討する。

\section{2 平行弦トラス平板の力学性状に対する偏心接合の効果}

Fig. 10 に偏心のないトラス平板と偏心接合したトラス平板の加 力点における荷重変形関係を示す。縦軸は荷重べクトルの大きさを, 横軸は載荷点での変位ベクトルの大きさを示している。荷重 $P$ は偏
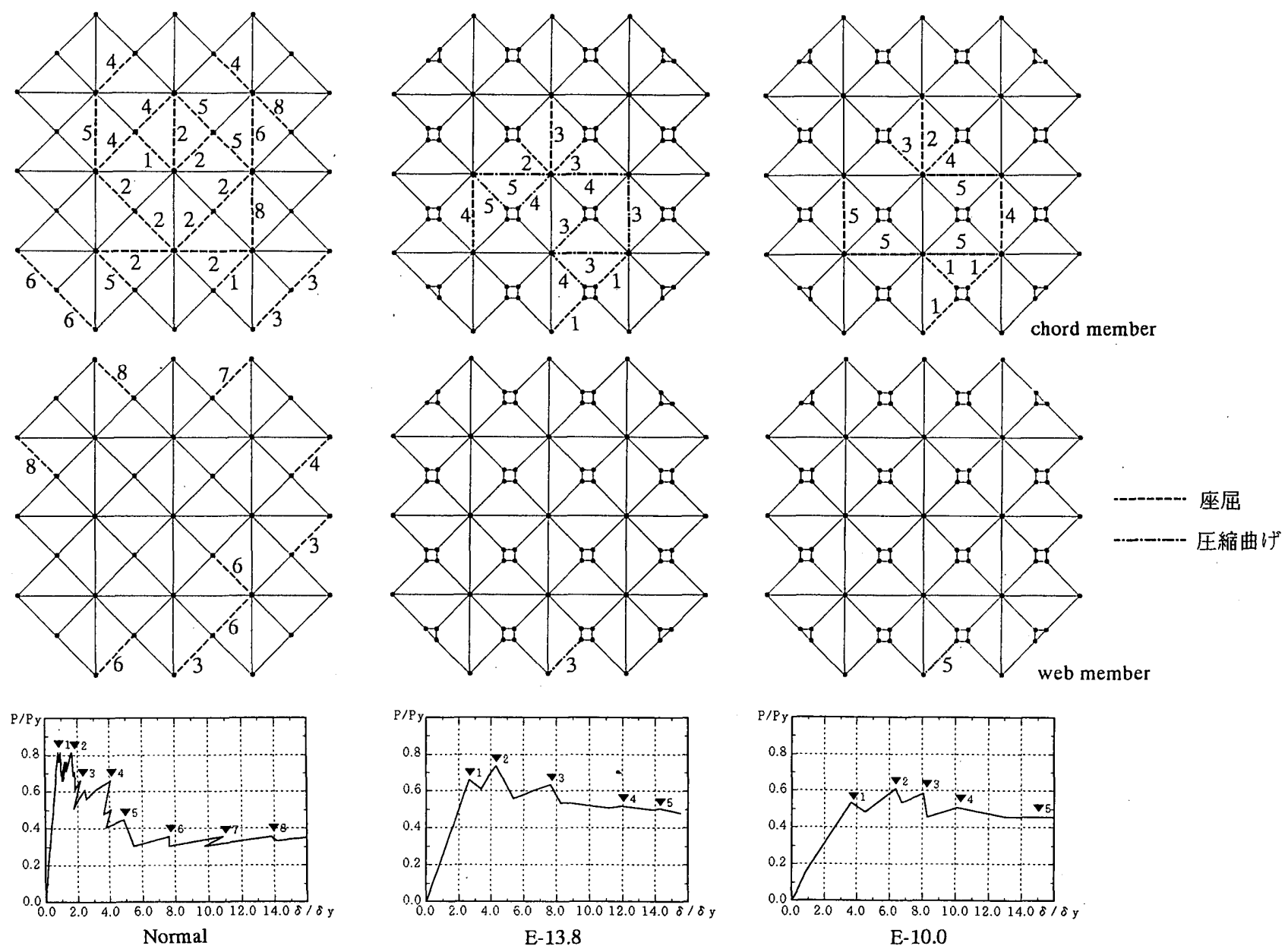

Fig. 11 Collapse mechanism 
心のないトラス平板の線形弾性解析において最大圧縮力を受ける弦 材の軸力が降伏軸力に達するときの荷重 $P_{y}$ で無次元化している。 また, 変位 $\delta$ は $P_{y}$ に対応する偏心のないトラス平板の弾性変位量 $\delta_{y}$ で無次元化している。各線は数值解析結果を，○，田は実験結果 を示している。偏心接合したトラス平板 E-13.8, E-10.0の数值解析 結果と実駼結果を比較すると，初期剛性，最大耐力そして全体の荷 重変形関係は良い对応を示しており，本解析手法によってトラス平 板の力学性状を概ね捉えることができる。偏心のないトラス平板は, $P / P_{y}=0.8$ で初期座屈が発生し，その後次々と生じる隣接部材の座 屈によって耐力を急激に低下させている。耐力停留值は $P / P_{y}=0.4$ よりも低くなっており，最大耐力の $50 \%$ 程度である。しかし，偏心 接合した E-13.8, E-10.0は, 偏心のないトラス平板に比べて初期剛 性, 最大耐力は多少低下するが, 最大耐力以降の劣化勾配は緩やか であり，耐力停留值も $P / P_{y}=0.5$ で偏心のないトラス平板よりも高 く最大耐力の $70 \%$ とっている。偏心接合したトラス平板は偏心の ないトラス平板に比へて初期剛性, 最大耐力は多少低下するものの, 最大耐力後の劣化勾配は緩やかになり，耐力停留值も高くなってい る。偏心接合材の風性を調節することで, 初期剛性, 最大耐力をコ ントロールすることが可能となり, 有用性の高い架構形式となりう る。

Fig. 11 に各トラス平板の崩壊メカニズムを示している。偏心のな いトラス平板は弦材で最初に座屈が生じると, 座屈した部材で受け 持てなくなった軸力が隣接部材に再配分され，それを引金として榉 接部材の座屈が次々と誘発され，急激な耐力劣化を示す。一方，偏

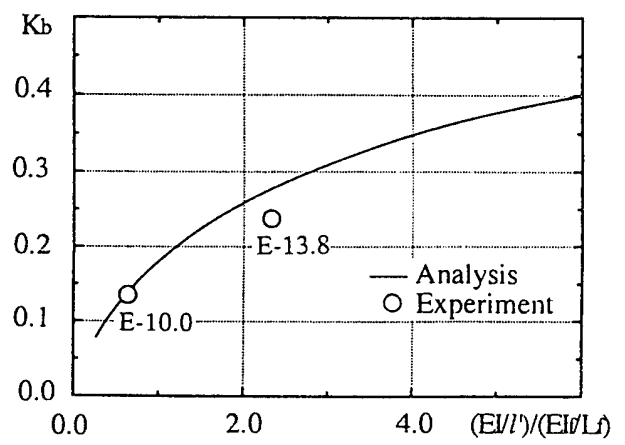

Fig. 12 Effect of bending stiffness of eccentric member for initial stiffness of space truss

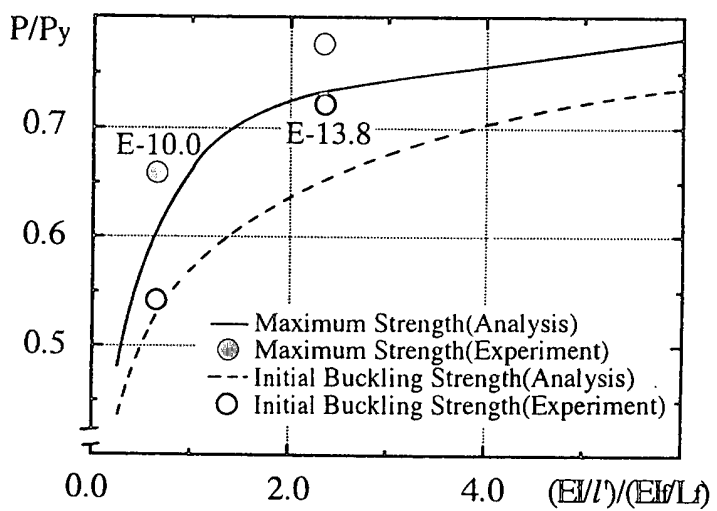

Fig. 13 Effect of bending stiffness of eccentric member for initial buckling and maximum strength of space truss

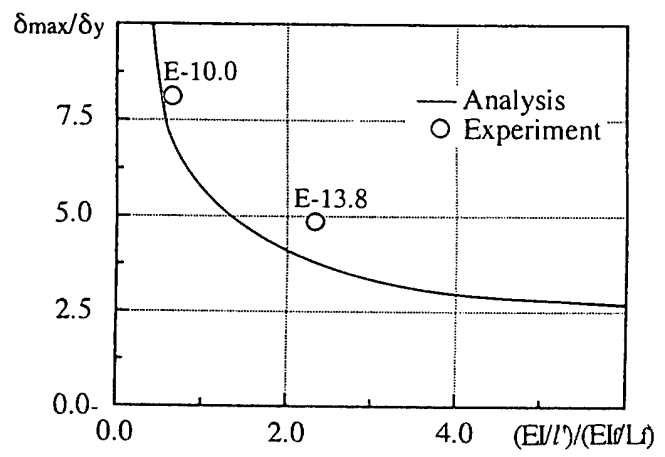

Fig. 14 Effect of bending stiffness of eccentric member for plastic deformation capacity of space truss

心接合したトラス平板では偏心接合部において接合材がせん断変形 し，トラス平板全体の変形を増大させるとともに偏心接合部で発生 する曲げ応力によって急激な応力変動を緩和しているものと思われ る。そのため, 平板全体の変形が進行しても座屈を経験する部材は 少なく, 安定した力学挙動を示している。偏心接合材の剛性が小さ いE-10.0は E-13.8に比べて座屈を経験する部材がさらに減少して いる。

偏心のないトラス平板では弦材等の座屈, 塑性化によって架構全 体の変形が進行するが，本論文で提案している偏心接合したトラス 平板ではこれらの変形に対して偏心接合部における接合材のせん断 変形が平板全体の変形に占める割合が大きくなっている。

Fig. 12 にトラス平板の初期剛性と接合材曲げ剛性との関係を示 す。縦軸はトラス平板の荷重変位関係より算定される剛性 $K b(=$ $\left.\left(P / P_{y}\right) /\left(\delta / \delta_{y}\right)\right)$ であり, 横軸は偏心接合材の曲げ剛性 $E I / l$ を弦材の 曲げ剛性 $E I_{f} / L_{f}$ で除した值である。

偏心接合によるトラス平板の剛性の低下は接合材の曲げ岡性が大 きく影響しており，偏心接合材の曲げ剛性を確保することで平板全 体の剛性は大幅に向上することが分かる。

Fig. 13 に偏心接合したトラス平板の耐力と接合曲げ剛性との関 係を示す。縦軸は平板の初期座屈耐力 $P_{c r}$, 最大耐力 $P_{\max }$ を降伏荷 重 $P_{y}$ で除しており, 横軸は Fig. 12 と同様の無次元化を行なってい る。トラス平板の剛性と同様に接合材の曲げ剛性を大きくすること で, 初期座屈耐力, 最大耐力は大幅に向上する。弦材と同じ径 $(\phi 16)$ を偏心接合材に用いた場合 $\left((E I / l) /\left(E I_{f} / L_{f}\right)=4.24\right)$, 偏心のないト ラス平板と同程度の耐力を確保することが可能となる。

Fig. 14 に偏心接合したトラス平板の最大耐力時の変形量と接合 材曲げ剛性との関係を示す。縦軸はトラス平板の最大耐力 $P_{\max }$ の 変形量 $\delta_{\max }$ を降伏荷重 $P_{y}$ 時の変形量 $\delta_{y}$ で, 横軸は Fig. 12 と同様 の無次元化を行っている。接合材の曲げ剛性を大きくすることで, トラス平板全体に対する偏心部でのせん断変形の寄与する割合は低 下し，最大耐力時の変形量は小さくなっていく。接合材の剛性を適 切に選択することで, トラス平板の初期剛性, 最大耐力を確保しつ つ，変形性能を向上させることができる。

\section{4. 結論}

本研究では圧縮弦材の個材座屈により急激に耐力を低下させるト ラス平板に対して，靶性を改善する目的で偏心接合したトラス平板 
を提案した。そして載荷実験及び数值解析によりこのようなトラス 平板の力学性状を明らかにし，偏心接合の影響を検討した。以下に 得られた結論を示す。

1）トラス平板の各部材を偏心接合することで，圧縮弦材の個材座 屈による急激な耐力低下は抑制される。このような平板の最大耐 力は初期座屈で決まらず, 座屈後も耐力を上䄯しつつ, 変形を伸 ばしている。

2 ）偏心のないトラス平板では一部の圧縮弦材が座風し，それを引 き金として隣接部材の座屈が誘発され，急激に耐力を低下させる。 しかし，偏心接合したトラス平板では，偏心部でせん断変形する ことで平板全体の変形が増大するため, 大変形域においても座屈 を経験する部材は少なく，安定した力学挙動を示す。

3) 偏心接合材の断面性能を適切に選択することで, 初期剛性をコ ントロールすることができる。最大耐力，最大耐力後の劣化勾配 は断面性能によらず，ほぼ等しくなっている。

4) 本研究で提案したトラス平板は, 単位ユニットトラスを偏心接 合することによって構成されるため, トラス構造物の構築作業は 簡略化され，精度の高いトラス構造が期待できる。

以上，偏心接合したトラス平板の基本的な力学性状を把握した。 今後, このような偏心接合したトラス平板について架構形式及び部 材形状等をパラメータとして，トラス平板の力学挙動にどのような 影響を与えるかを検討し，偏心接合の効果を定量的に把握していく とともに，より適切な接合部形式を検討することで害用化を図って いく予定である。

\section{参考文献}

1) Paris. P.C : Limit Design of Column Journal of Aeronautical Science, 1954.1

2) GAR Parke and HB Walker : A Limit State Design of Double-Layer Grids, 3rd International Conference on Space Structures, pp. $582 \sim 532,1984.9$

3）鉿木敏郎, 久保寺勲, 小河利行：鉄骨トラスばりの耐力と塑性変形性状に 関する実験研究（トラス構造物の耐震性に関する研究(1)），日本建築学会 構造系論文報告集，第 360 号，pp. $75 \sim 82 ， 1986.2$

4）鈴木敏郎, 久保寺薁, 小河利行：鉄骨トラス骨組の復元力特性と耐震性評 価方法（トラス構造物の耐震性に関する研究(2))，日本建築学会構造系論 文報告集，第365号，pp.28 38, 1986.7

5）二層立体ラチス構造の解析・設計・施工一その現状と問題点一，日本建築 学会空間骨組小委員会二層立体ラチス構造研究班, 1992.11

6) T.SUZUKI, T.OGAWA, Y.TSUSHIMA, M.KIMURA and H.KANE $\mathrm{KO}$ : Stability of a space truss composed of square pyramid units. Space structures 4,pp.78 88.1993

7）鈴木敏郎, 小河利行, 久保寺勲,五十風規矩夫：ボール接合単層ラチスドー 厶の座屈実験及び弹塑性座屈解析, 日本建築学会構造系論文集, 第444号, pp. $53 \sim 62,1993.7$

8）向 秀元, 渡辺 厚, 岩田 衛, 和田 章: トラス構造の靶性性能改善に 関する縮小模型実験, 日本建築学会構造系論文集, 第448号, pp. 141～152, 1993.6

9）小野徹郎, 对馬義幸, 岩田 衛: 水平荷重を受ける剛接合立体卜ラスの酎 力. 変形性状について，日本建築学会構造系論文集，第449号， pp. $175 \sim 183,1993.7$

10）小野徽郎，対馬義幸，岩田 衛：人工地盤を想定した剛接合立体トラスの 実驗的研究，日本建築学会構造系論文集，第457号，pp.37４6，1994.3

11）山中 徽, 鈴木敏郎, 小河利行, 福岡庿一, 小久保隆博：偏心接合を有す る平行弦トラス平板の座屈性状に関する研究（その1）実験概要，日本建 築学会学術講演梗概集, pp.1893 1894, 1994.9

12）小久保隆博，鈴木敏郎，小河利行，福岡庸一，山中 徽：偏心接合を有す る平行弦トラス平板の座屈性状に関する研究（その2）偏心接合部と崩壊 形式，日本建築学会学術講演梗概集，pp.1895 1896，1994.9

13）鈴木敏郎，小河利行，五十嵐規矩夫，木村祥裕：中間材を導入した鋼管卜 ラス梁の力学性状に関する研究, 日本建築学会構造系論文集, 第 470 号, pp.123 131，1995.4

14）鈴木敏郎，小河利行，木村祥裕，石原 直：压縮弦材を偏心接合した複層 立体卜ラス構造の力学特性に関する研究, 日本建築学会構造系論文集, 第 497号, 1997.7

(1997年 6 月10日原稿受理，1997年11月 5 日採用決定 